Mirjam Künkler. Assistant Professor in the Department for Near Eastern Studies at Princeton University, USA. She has published on religion-state relations and Islamic thought in $20^{\text {th }}$ century Iran and Indonesia, and edited with Alfred Stepan, Indonesia, Islam and Democracy, Columbia University Press (2013), and with John Madeley and Shylashri Shankar, A Secular Age: Beyond the West, (2015). Her articles have appeared or are forthcoming in the journals Comparative Studies of Society and History, Journal of the Royal Asiatic Society, Journal of Law and Religion, Democratization, Politics and Religion, Journal of International Affairs, Party Politics, as well as in edited volumes. In her next project, she turns to questions about the post-revolutionary transformation of the legal system in the Islamic Republic of Iran, and female religious authority in Shi'i Islam. Künkler is co-PI of the Oxford-Princeton research cluster on "Traditional authority and transnational religious networks in contemporary Shi'i Islam," and of the "Iran Social Science Data Portal" funded by the Social Science Research Council (SSRC).

Contact:kuenkler@priceton.edu 


\title{
LAW, LEGITIMACY AND EQUALITY The Bureaucratization of Religion and Conditions of Belief in Indonesia
}

\author{
Mirjam Künkler \\ Princeton University, USA
}

Reception date October $14^{\text {th }}$ 2014; Acceptance date November $7^{\text {th }} 2014$. This article is the result of an investigation project developed at the Department for Near Eastern Studies at Princeton University.

\section{Abstract}

Secularity in the sense of a social imaginary, an appreciation for the differentiation between religious and political authority, and the acknowledgement of religious plurality surely exist. While, like Senegal and Turkey, Indonesia is a Muslim state that is in the process of translating democracy into its own institutional legacies and of crafting its own brand of democratic religion-state relations, it is probably unique as a case where, although religious and political authority is separated, citizenship is tied to religion. This implies that one's declared religious affiliation determines the type of religious education and personal law one will be subject to. And there is more: religions are in some ways highly regulated by the state. As the author will argue in the following, in an effort to subsume all social and civic life in the two post-independence authoritarian regimes (1945-1965 and 1965-1998) to the twin goals of political order and economic growth, state bureaucrats sought to 'modernize' religion and thereby highly bureaucratized it. Religion in post-independence Indonesia was not only made 'manageable' but also put into the service of government policy.

\section{Keywords}

Secularization, citizenship, freedom of religion, political identity. 


\section{Resumen}

La laicidad, como imaginario social, como atención hacia la diferenciación entre autoridad religiosa y política y reconocimiento de la pluralidad religiosa, en la Indonesia de la post-independencia sin lugar a dudas existe. Si, por una parte - tal como Senegal y Turquía - Indonesia es un Estado islámico a punto de introducir la democracia en su sistema institucional tradicional y de elaborar un modelo propio de las relaciones religión-estado en sentido democrático, por otra parte es el único Estado en el que la ciudadanía está relacionada con la religión, aunque religión y autoridad política estén separadas. Esto implica que la pertenencia religiosa determina el tipo de educación religiosa y el "derecho de la persona” al cual uno está sometido. Además, las religiones están, pues, fuertemente reglamentadas por el Estado. Tal como subraya la autora en este artículo, con la intención de englobar toda la vida social y civil en los dos regímenes autoritarios de la post-independencia (1945-1965 e 1965-1998) para llegar al objetivo del orden político y del crecimiento económico, los burócratas estatales han intentado "modernizar" la religión, burocratizándola profundamente. En la Indonesia de la post-independencia, la religión no solo ha sido convertida en "manejable", "accesible", sino también ha sido entregada al servicio de las políticas del Gobierno.

\section{Palabras clave}

Secularización, ciudadanía, libertad religiosa, identidad política.

\section{Introduction}

If secularity involves the move from a society where belief in God is in principle unchallenged to one where it is one option among others (Taylor's Secularity III), post-independence Indonesia (1945-) is not secular. If modern secularity is a field of increasingly 'multiform contestation', Indonesian society is not a secular society. It is unsecular by law, in that Indonesian citizenship is tied to religion. It is impossible to register as an atheist, agnostic, or adherent of one of the non-recognized religions in Indonesia. One can also hardly speak of multiform constestation in that religions hardly compete with one another. Conversion rates are very low and proselytization prohibited. Yet secularity in the sense of a social imaginary, an appreciation for the differentiation between religious and political authority, and the acknowledgement of religious plurality 
(Taylor's Secularity I) surely exist. With that simultaneity of state-induced impossibility of Charles Taylor's secularity III, with socially embedded understanding of secularity I, the case of Indonesia presents a case of its own. While, like Senegal and Turkey, it is a Muslim state that is in the process of translating democracy into its own institutional legacies and of crafting its own brand of democratic religion-state relations, it is probably unique as a case where, although religious and political authority is separated, citizenship is tied to religion. ${ }^{1}$ This implies that one's declared religious affiliation determines the type of religious education and personal law one will be subject to. And there is more: religions are in some ways highly regulated by the state. As I will argue in the following, in an effort to subsume all social and civic life in the two post-independence authoritarian regimes (1945-1965 and 1965-1998) to the twin goals of political order and economic growth, state bureaucrats sought to 'modernize' religion and thereby highly bureaucratized it.

What are the conditions of belief in such a state, where 'freedom of conscience' in the sense that non-religion is an option and that there is religion outside state-sanctioned perimeters does not exist?

\section{Bureaucratization: The Response of a "Pan-religious" Indone- sian State to Questions of Religion and Religious Identity}

Indonesia is a multi-religious, multi-cultural and pluri-legal state. Its $86 \%$ Muslim majority is internally highly heterogeneous and bound together more by the overall label than agreement in matters of faith and notions of religious law. Its minority of Christians (9\%), Buddhists (3.5\%) and Hindus (1.5\%) are also internally highly heterogeneous. After independence in 1945, the Indonesian leaders faced the very same question that the founders of India encountered: what kind of state should Indonesia become, and should the state be based on a core ethos? Like India, despite the existence of an overwhelming religious majority, Indonesia was also a multi-religious, multi-linguistic and pluri-legal society. In addition to Islam and Christianity, ancient traditions of Buddhism, Hinduism, Confucianism as well as several dozen indigenous belief sys-

\footnotetext{
1. Senegal, Turkey, and Indonesia, together with Albania and Mali belong to the five countries in the Muslim world that underwent democratization processes and were coded, in the three indices on regime type considered most authoritative in the discipline of Political Science (Polity IV, Freedom House, BTI), as democracies between 2000 and 2011. See, for instance, M. Künkler, "Religion-State Relations and Democracy in Egypt and Tunisia: Models from the Democratizing Muslim World -and their Limits", in Swiss Political Science Review, 18, 2012, pp. 114-119.
} 
tems existed across the archipelago. In the process of state and nation-building, the founding elite decided that in order to overcome existing schisms and attain national unity, they had to strive for the homogenization of diverse religious cultures and identities, and do away with the fragmented colonial legal system which, they believed, was unfit for a unitary modern nation-state.

Before independence in 1945, the country's judicial system had been separated into colonial, customary (adat) and Islamic legal systems. Customary legal systems existed side by side in those areas ruled indirectly, with 19 different jurisdictions based on cultural and linguistic particularity. Customary law was not codified and applicable only in matters where no civil law statute yet existed. In some regions, customary courts were eliminated in the early years after independence in 1945, in others, where separatist struggles were fought, their phasing out occurred more gradually and was completed only in $1969 .{ }^{2}$ While the central state succeeded in gradually eliminating customary courts from region to region, the same was not true for Islamic courts. Since mobilization in favor of their retainment was centralized (in contrast to the customary courts where mobilization was region-based), the central state did not succeed in doing away with the Islamic courts and in unifying the court system entirely. As will be further discussed below, Islamic courts survived and the duality of qadi courts (applying Islamic family law) versus secular courts exists until today. ${ }^{3}$

Against the background of the great plurality in culture, religion and legal traditions, the founders recognized that in order to preserve the territorial unity of the new state, they had to accommodate cultural particularity and allow at least some degree of religious and legal diversity. Thus, the motto of Indonesia became "Bhinneka Tunggal Ika" or "Unity in Diversity." Against this background, the founders were particularly preoccupied with the question of what role religion, especially Islam, was to play: on the one hand, after centuries of colonial rule, here was a chance to create a state where Islam would be the primary source of law. On the other, cultural norms that created and conserved great diversity across the archipelago would make a shared and uniform understanding of Islamic law difficult, and the proclamation of an Islamic State (Negara Islam) might provoke non-Muslim islands in the East of the archipelago to se-

\footnotetext{
2. By the time the center had eradicated all separatist struggles in 1969 , the last customary courts were replaced by national state courts.

3. Islamic law had first been recognized as law in the 1882 Royal Decree establishing a "priest court" in Java and Madura, with jurisdiction over awqaf (religious endowments), and Muslim family and inheritance law in cases where all parties were Muslim. The priest court enjoyed concurrent jurisdiction with the regular ("native") courts in Java and Madura. The priest court was composed of a President selected from officers of the regular courts, as well as three to eight Islamic judges (qadis), who were all appointed by the Governor-General.
} 
cede. Ultimately, the final version of the constitution that the drafting committee agreed upon was not that of an Islamic state but a state with equal citizenship for Muslims and non-Muslims alike. That the state should nevertheless have an ethical mandate, if it should not have an explicitly Islamic one, was a matter members of the constitutional drafting committee felt strongly about: religion should matter for Indonesian-ness. A list of five ethical principles was adopted in the preamble to the 1945 constitution that commit Indonesians to (1) the belief in the one and only God, (2) a just and civilized humanity, (3) the unity of Indonesia, (4) democracy guided by the inner wisdom of unanimity arising out of deliberations among representatives, and (5) social justice. ${ }^{4}$

These five principles, called 'pancasila' (notably Sanskrit rather than bahasa Indonesia or Arabic), were developed by nationalist leader Sukarno, who later became the country's first president. ${ }^{5}$ Muslim modernists in principle accepted Sukarno's pancasila, but demanded that a clause stipulating the implementation of Islamic law accompany the first principle: Belief in one God with the obligation to implement the sharic a for adherents of Islam. This supplementary clause, which came to be known as the 'Jakarta Charter', was accepted in the drafting committee on June 22, 1945. Nearly two months later, however, when the committee convened again to sign the constitutional preamble on August 18, 1945, the seven words of the Jakarta Charter were dropped from the final version due to the fear that non-Muslim regions would secede if Islamic law were to be enforced. ${ }^{6}$ Three further changes had taken place by August 18: the Arabic word for "preamble", mukaddimah, was replaced by the Indonesian pembukaan; in paragraph 6 the provision that the president of Indonesia be Muslim was deleted; and in one formula which suggested that Indonesian independence had been achieved by the grace of

\footnotetext{
4. The 1945 constitution (Undang Undang Dasar 1945) does not adopt an official religion, but Art. 29(1) provides that "the State is based upon the belief in the One, Supreme God." Meanwhile, Art. 29(2) guarantees freedom of religion [albeit only for the recognized religions]. Apart from tribal religions, there are also significant Muslim minorities, such as Ahmadis and Shias, who are not recognized.

5. Sukarno first presented the pancasila on June 1, 1945 in his speech later designated "the birth of pancasila." Sukarno's thinking exposed distinct parallels with Islamist thought - however intentional and possibly instrumental this may have been. He explicitly drew parallels between the fourth principle and Islamic concepts of musyarawat (consultation) and mufakat (consensual unanimous decision-making arising out of such consultation). In contrast to Islamists, however, Sukarno believed strongly in a separation of religion and state, not only for the sake of national unity, but also notably for the sake of religion, remembering that state interference in religious matters under the Dutch administration had significantly compromised religious leaders.

6. See G. Forrester, R.J. May (eds.), The Fall of Soeharto, Crawford House Publishing, Bathurst, 1998, p. 56. That Eastern Indonesia would break away is also what Sukarno argued in his controversial 1953 speech in Mauntai, Kalimantan. Feith holds that the speech had a powerful polarizing effect on the pancasila vs. Islamic state debate and that it was only after 1952 that Muslim leaders openly spoke out against Pancasila. The term 'nationalist' from now on acquired a secularist overtone while Islamic forces such as the Islamic party Masyumi would have seen no contradiction between Islam and nationalism in the 1940s; see: H. Feith, The decline of constitutional democracy in Indonesia, Cornell University Press, Ithaca (N.Y.), 1962, pp. 281-282.
} 
Allah, the word 'Allah' was replaced by "Tuhan yang Maha Kuasa”, bahasa Indonesia for 'Almighty God'.

Confronted with these consequential changes in the preamble and the constitution, Islamic groups temporarily withdrew their support from the national government. Only the appearance of the Allied powers in the fall of 1945 and the consequent attempt by the Netherlands to re-occupy the country swayed them to renew their loyalty to Jakarta. Reluctantly, regional elites who had hoped for the establishment of an Islamic state complied with the new constitution, fully expecting that within a year or two, a constituent assembly would be elected in the country's first free and fair elections that would draft a new constitution and replace the Pancasila state by an Islamic state. ${ }^{7}$

Amid Dutch attempts to reoccupy the country after WII, these elections, however, were not held until a full decade later. Even once the constituent assembly ("Konstituante") was elected in 1955 and between 1956 and 1959 deliberated over a new constitution, the two-thirds majority needed for turning Indonesia into an Islamic state could not be reached. By 1959, president Sukarno was so frustrated with the inability of the Konstituante to reach a consensus that he reinstated the 1945 constitution and re-affirmed pancasila without the Jakarta Charter, that is, without the duty for Muslims to abide by Islamic law. The unitary, non-Islamic, but pan-religious formula that had been agreed upon in 1945 henceforth became the most characteristic feature of post-independence Indonesia.

\section{The policy of Agamasasi: Turning "religion" into the building block of Indonesian national identity}

Pancasila proved very useful in providing a pan-religious national ethos to a pluralistic society, and could have been a window of opportunities for positive and negative religious freedom. However, this potential freedom was soon undermined by the Indonesian state's policy of requiring religions to be recognized as such by the state. With this approach, the Indonesian policy towards religion closely resembled that of Japan where

7. Indeed, the first national elections were originally planned for January 1946. It is interesting to note that the provision of the 1949 Hague Agreement between the Netherlands and Indonesia, which would have transformed Indonesia into a federal state, opened up the increased possibility of the revival of the Jakarta Charter, because it necessitated a new constitution and because it would have allowed for the implementation of Islamic law in the Muslim-majority federal units while not in others. The fact that this possibility was opened up by the disdained Dutch allowed the advocates of pancasila to portray Islamist voices as 'anti-nationalists' who bought into the Dutch trap that would split up Indonesia. 
Shintoism was elevated to a pan-religious ethos and where government-designed categories of religious organizations deeply shaped the content and character of religious life, as religious groups had to 'qualify' within bureaucratic categories to avoid being shut down. ${ }^{8}$

Citizenship in Indonesia was henceforth tied to religion. Being an adherent of a state-recognized religion (agama) was required of every Indonesian to be considered a full citizen. According to a 1952 regulation issued by the Ministry of Religious Affairs (MORA), the Indonesian government defined agama as an internationally recognized monotheistic creed with a Holy Scripture, the concept of prophethood and universal ethical teachings. Belief systems that did not meet these criteria were denied government recognition and their adherents denied the right to celebrate birth, marriage, burial etc., according to their beliefs. They would also not be protected by the religious freedom clause enshrined in the national constitution. In the political and legal usage, agama as a state-recognized religion was distinguished from kepercayaan, non-theistic belief systems. ${ }^{9}$ Those who did not profess one of the state-recognized religions were referred to as "orang yang belum beragama", people who do not yet (!) have a religion (e.g., Dayak, Toraja, Karo Batak etc.) "implying that they would need to adopt an agama if they were to become full participants" in the new state. ${ }^{10}$ Official identification cards listed the person's religious affiliation and Indonesians who wanted to enter the military or public service needed to prove that they were a member of a state-recognized agama.

Unlike the Indian regime which delegated the controversial task of delineating what a religion is to the judiciary, the Indonesian government instead followed the Japanese model and utilized the bureaucracy. During the occupation of 1942-1945, the Japanese administration had founded the Office of Religious Affairs in Indonesia which was modeled on its own office at home, that stipulated what a true religion was. ${ }^{11}$ After independence, the young state of Indonesia transformed the Office of Religious Affairs

8. See W.T. De Bary, C. Gluck, A.E. Tiedemann, W.J.J. Boot, W.M. Bodiford, Sources of Japanese tradition. Part II (18682000), Columbia University Press, New York, 2006, pp. 118-121; H. Hardacre, Shinto and the State (1868-1988), Princeton University Press, Princeton (N.).), 1989.

9. See I. Chalmers, Indonesia: an introduction to contemporary traditions, Oxford University Press, South Melbourne (Vic.), Oxford, 2006, p. 125; A. Schrauwers, Colonial "reformation" in the highlands of Central Sulawesi, Indonesia (1892-1995), University of Toronto Press, Toronto, 2000, p. 57; L.V. Aragon, Fields of the Lord: animism, Christian minorities, and state development in Indonesia, University of Hawaii Press, Honolulu, 2000, pp. 15, 33, 325.

10. I. Chalmers, Indonesia: an introduction to contemporary traditions, p. 125.

11. See M.A. Aziz, Japan's Colonialism and Indonesia, M. Nijhoff The Hague, Leyden, 1955 (issued also as thesis), pp. 200208; H.J. Benda, The Crescent and the Rising Sun: Indonesian Islam under the Japanese ccupation (1942-1945), W. van Hoeve, The Hague, 1958, pp. 132-149; C.A.O. Van Nieuwenhuijze, Aspects of Islam in post-colonial Indonesia, W. van Hoeve, The Hague, 1958, p. 116. 
into the Ministry of Religious Affairs (MORA). The 1952 regulation explicitly rejected non-theistic belief systems, including Hinduism, Buddhism, Confucianism and other indigenous faiths and referred to them as "dogmatic opinions that belonged to tribes which were still backward." 12 Thus, it was made clear by the government that if members of kepercayaan (currents of belief) wanted to become full members of a progressive nation, they had to homogenize and rationalize their belief systems along monotheistic lines. The adherence to faiths that not only hampered the progress of the nation but also openly clashed with the founding ethos of the republic (i.e. pancasila) was adverse to full membership in the political community.

Upon its founding, the MORA initially recognized three religions (agama): Islam, Protestantism and Catholicism. In 1958 Hinduism and in 1965 Buddhism were recognized, after they each underwent a state-induced process of 'reform' along monotheistic lines. ${ }^{13}$ These processes of agamasasi ('religionization') required the revivification and "reinvention" of ancient traditions, rituals, narratives and texts as well as the prioritization of certain elements over others in order to locate an omnipotent, omniscient and omnipresent supreme deity, a Holy Scripture and a prophet.

The experience of Balinese Hinduism, in this respect, is particularly instructive. In order to meet the criteria put forth by the MORA and the principles of pancasila, Hindu Balinese intellectuals under the pressure from the government rebuilt the Hindu belief system following a monotheistic model. In order to emphasize oneness of the nation and God, they promoted Brahman to the "supreme god" and gave him an Indonesian name, Sang Hyang Widhi Wasa, while turning other gods into his "angels" and "saints." The Vedas, Ramayana and Bhagavad Gita were declared the equivalent of the Qur'an or the Bible, and the Vedic sages (rishis) became "prophets." ${ }^{14}$ The worship Trisandhya was transformed into three-times-a-day prayer, equivalent to Islamic salat. And like the Indian judiciary, the Balinese Hindu community also reinvented the universal teachings

12. M. Ramstedt, "Introduction: Negotiating Identities - Indonesian 'Hindus' between Local, National, and Global Interests", in M. Ramstedt (ed.), Hinduism in Modern Indonesia: a Minority Religion between Local, Rational, and Global Interests, Routledge Curzon, London-New York, 2004, p. 9.

13. See J.D. Howell, "Indonesia: Searching for Consensus", in C. Caldarola (ed.), Religions and Societies, Asia and the Middle East, Mouton, Berlin-New York, 1982, pp. 511-517. The government's policy towards Confucianism was contradictory. First recognized as a sixth official religion in 1965, Confucianism was removed from the list in a 1979 cabinet decision against in the backdrop of rising anti-Sinism during Suharto's New Order (see Y. Heriyanto Yang, "The History and Legal Position of Confucianism in postindependence Indonesia”, in Marburg Journal of Religion, 10, 2005, pp. 1-8; A.J. Abalahin, "A Sixth Religion? Confucianism and the Negotiation of Indonesian Chinese Identity under the Pancasila State", in A. C. Willford, K. M. George (eds.), Spirited Politics: Religion and PublicLife in Contemporary Southeast Asia, Southeast Asia Program, Cornell University Press, Ithaca (N.Y.), 2005).

14. J. Mcdaniel, "Agama Hindu Dharma Indonesia as a New Religious Movement: Hinduism Recreated in the Image of Islam", in Nova Religio: The Journal of Alternative and Emergent Religions, 14, 2010, pp. 96-97. 
and central tenets of their faith resembling the five pillars of Islam (e.g., dewa yadnya or worship to God, pitra yadnya or devotion to ancestors, manusia yadnya or devotion to mankind, bhuta yadnya or reverence to lower beings and resi yadnya or devotion to spiritual teachers). ${ }^{15}$ The process of agamasasi was essentially very similar to the judiciary-sanctioned process of Semitization of religions in India. ${ }^{16}$ Taylor does at length describe the demands placed on Latin Christendom and on the Catholic Church with the emergence of the modern state and later notions human rights and religious tolerance, but nothing in his account even approaches the intrusiveness of state policies toward religion experienced in the Indonesian case.

The MORA's pressure on non-theistic "currents of belief" to universalize or Semitize became more pronounced after general Suharto's ascent to power in October 1965. Under the "New Order", as Suharto's regime came to be called, anyone who did not profess a recognized religion risked being identified as an atheist and by association a communist. ${ }^{17}$ Massive anti-communist pogroms characterized the early years of the New Order, to which more than half a million fell victim. The pressure on Confucianism, yet unrecognized as agama, was therefore particular strong. Many of those who were originally adherents of the so-called aliran kepercayaan were forced by the government to either relinquish their 'backward' faiths or to transform and integrate them into an existing agama. Between 1966 and 1980 mass conversions into Islam and Christianity, and to a lesser extent Buddhism and Hinduism, took place especially among adherents of indigenous belief systems in Central and East Java, South Sulawesi, North Sumatra, and Central and North Kalimantan. ${ }^{18}$ As Schiller demonstrates $^{19}$, Indonesian bureaucrats were inclined to interpret indigenous practices as varieties of the recognized religions and register their adherents as members of these major traditions in order to attain religious, and cultural homogeneity and create the ideal Indonesian citizen ('manusia pancasila' - the Pancasila man/woman). ${ }^{20}$

15. See M. Ramstedt, “Introduction: Negotiating Identities - Indonesian 'Hindus' between Local, National, and Global Interests", pp. 11-12.

16. See R.W. Hefner, “Hindu Reform in an Islamizing Java: Pluralism and Peril”, in M. Ramstedt (ed.), Hinduism in modern Indonesia, p. 97.

17. See K. O'Shaughnessy, Gender, State and Social Power in cContemporary Indonesia: Divorce and Marriage Law, Routledge, London-New York, 2009, p. 169.

18. See M. Ramstedt, "Introduction: Negotiating Identities - Indonesian 'Hindus' between local, national, and global interests", p. 17; R.W. Hefner, "Hindu Reform in an Islamizing Java: Pluralism and Peril”, p. 105; J.T. Ginting, "The Position of Hinduism in Karo Society (North Sumatra)" in M. Ramstedt (ed.), Hinduism in modern Indonesia, p. 226.

19. See A. Schiller, “An 'Old' Religion in 'New Order' Indonesia: Notes on Ethnicity and Religious Affiliation”, in Sociology of Religion, 57, 1996, pp. 409-417.

20. M. Ramstedt, "Introduction: Negotiating Identities - Indonesian 'Hindus' between local, national, and global interests", p. 17. See also K. O’Shaughnessy, Gender, state and social power in contemporary Indonesia: divorce and marriage law, p. 169. 
By doing so, authorities were not only converting people from an aliran kepercayaan to a recognized religion (agama), but also inducted them into Indonesian citizenship. $^{21}$

\section{Religion and religious law at Indonesian courts}

How did the politics of religion play out in the law? Like their Indian counterparts, Indonesian leaders were keen to put an end to the multiplicity of legal systems after independence and unite the nation under one law. ${ }^{22}$ Adat, or customary law, was particularly targeted by nationalist, Islamist and socialist leaders due to its "feudal, imperialist and anti-republican connotations." ${ }^{23}$ As noted, customary law was gradually out-phased and replaced by positive state law. Islamic law, however, was more difficult to abolish. The state, which fought a war of independence against the Dutch from 19451949 , simultaneously fought secessionist movements across the islands that advocated the establishment of an Islamic state. Throughout these struggles, the military gained in political prominence and by 1966 an army general, Suharto, had taken hold of the government and with foreign help ousted the country's first post-independence president Sukarno. From 1966 until the country's democratization in 1998, Indonesia was a military regime with a highly developmentalist outlook. Being marginalized since the failure of the Konstituante in 1959 and the establishment of Sukarno's "Guided Democracy" (a coalition of nationalists, communists and socialists), Islamic groups had assisted the military takeover in 1966 and participated prominently in the pogroms against so-called communists in 1965-66. Since the Muslim modernist party Masyumi had been banned by Sukarno in 1960, Islamist and Islamic leaders hoped for the revival of political Islam in Suharto's "New Order" and were thus bitterly disappointed when Suharto upheld the ban of Masyumi, and in 1973 went so far as to "simplify the party system", in whose context the only remaining Islamic political parties were forced to merge with others into one of two official opposition parties.

\footnotetext{
21. See P. Freston, Evangelical and Politics in Asia, Africa and Latin America, Cambridge University Press, 2001, Cambridge, p. 81 .

22. See A. Salim, Challenging the Secular State: the Islamization of Law in Modern Indonesia, University of Hawaii Press, Honolulu, 2008, p. 75.

23. M. Ramstedt, "Introduction: Negotiating Identities - Indonesian 'Hindus' between local, national, and global interests", p. 8. See also R. Lukito, "Law and politics in post-independence Indonesia: a case study of religious and adat courts", in A. Salim, A. Azra (eds.), Sharia and politics in modern Indonesia, Institute of Southeast Asian Studies, Singapore, 2003; D.S. Lev, Legal evolution and political authority in Indonesia: selected essays, Kluwer Law International, The Hague, 2000, pp. 33-70.
} 
In compensation, Suharto gave in to two Islamist demands. He set up an Indonesian Ulama Council (MUI) in 1976 that gave representation to leading modernist thinkers and scholars and issued fatwas on urgent legal questions and dietary issues. Secondly, Suharto and the military watered down the draft Marriage Law that was eventually passed in 1974. Initially, the marriage law was envisioned to make marriage exclusively a civil matter by stipulating that "a marriage is valid if it is performed before an official marriage registrar." ${ }^{24}$ In contrast to the dominant interpretation of Shafi i $i$ fiqh, the law would have required only the consent of the marrying parties, rather than the guardian of the woman, and would have set the minimum marriage age at 18 for the woman and 21 for the man. Most importantly, by making family matters a civil law issue, the law would have de facto made the Islamic courts superfluous, since by default, custody and divorce cases would also have become civil matters. After an informal compromise was reached between the military and Islamic representatives, a Marriage Law was passed that distinguished between marriages that were 'valid', and marriages that were 'legal.' Marriages that fulfilled the known standards of an Islamic marriage contract (with lower minimum age and parents' required consent) were 'valid', whereas to be 'legal' from a civil law point of view, marriages had to fulfill certain standards as specified in the Marriage Law. For instance, the 1974 law prohibited polygyny for civil servants. For ordinary citizens, polygyny was made more difficult as it required the written consent of the first wife accompanied with proof that she was unable to perform her duty as a wife. It also required proof on part of the husband that he had the material means to support more than one wife and their offspring.

The continued duality of Islamic law for Muslims versus civil law for the religious minorities was exemplified in the fact that Muslim marriages were registered with the Department of Religious Affairs, while the registration of all other marriages (Buddhist, Hindu, Christian) was undertaken with the Ministry of the Interior. While ultimately, the 1974 Law slightly increased the jurisdiction of sharia courts, it demanded that the courts applied Shafi $i$ fiqh in the framework of larger civil law regulations on marriage age, polygamy, alimony etc. In fact, as Federspiel holds, most state judges until 1991 considered the sharia courts as advisory, issuing fatwas, rather than producing binding rulings.

Since until 1991, Islamic law was uncodified and judgments therefore unstandard-

24. M. Cammack, L.A. Young, T. Heaton, “Indonesia’s Marriage Law”, in T. Lindsey (ed.), Indonesia: Law and Society, ISEAS, Singapore, 2008, p. 301. 
ized, the Ministry of Religion and Supreme Court judges in 1991 issued a compilation of Islamic law (Kompilasi Hukum Islam - KHI) that was to give some direction as to the most authoritative opinions and regulations that judges in the qadi courts ought to invoke. ${ }^{25}$ Obviously, the compilation was not a code for qadis to follow, but it narrowed the range of interpretations for qadis to use, and quickly replaced citations of the Islamic books previously used (the so-called ketab kuning, classical books of Shafi i fiqh). Though the New Order had still not been able to make Islamic family law entirely a state issue, the compilation presented an important step towards the nationalization and bureaucratization of Islamic law and the unification of Muslim jurisprudence across the archipelago. ${ }^{26}$ Indeed, as qadi courts were now clearly recognized as courts of first instance for Muslim family matters, "religious court judges began to see themselves as part of the wide state bureaucracy and law enforcement apparatus, rather than upholders of Islamic law." ${ }^{27}$ In this regard, the compilation was in accord with the regime's long-term goals of bureaucratization of religion and legal unification.

The New Order often stressed the desirability of a single system of national law, that is, codified, single law derived from Indonesia's diverse adat, religious, colonial and post-independence laws that would apply to all members of the population, regardless of ethnicity or belief, as it strongly believed in the constitutive power of law that would transcend local divisions, and further strengthen the national identity. ${ }^{28}$

The family matters of the other four recognized religions continued to be dealt with in the civil courts. Although the law did not explicitly prohibit inter-religious marriages, it is often interpreted to preclude unions between adherents of different religions, because marriage is defined as a contract carried out according to belief system and the religion of both parties. ${ }^{29}$ In 1983, Suharto solidified the government's anti-inter-religious marriage stance with a decree that de-authorized civil registries to register mixed marriages where one partner was a Muslim. The 1991 Compilation of Islamic Law

\footnotetext{
25. Since the 1991 compilation is a presidential instruction (Inpres), it enjoys a lower status than regular statutes. 26. See E. Nurlaelawati, Modernization, Tradition and Identity: The Kompilasi Hukum Islam and Legal Practice in the Indonesian Religious Courts, University of Amsterdam Press, Amsterdam, 2010; A.I. Mawardi, Socio-Political Background of the Enactment of Kompilasi Hukum Islam Di Indonesia, Institute of Islamic Studies, McGill University, Montreal, 1998. 27. S. Butt, "Polygamy and Mixed Marriage in Indonesia: Islam and Marriage Law in the Courts", in T. Lindsey (ed.), Indonesia: Law and Society, ISEAS, Singapore, 2008, p. 274. 28. Ibid., p. 269.

29. See K. O'Shaughnessy, Gender, State and Social Power in Contemporary Indonesia: Divorce and Marriage Law, p. 170.
} 
(KHI) went one step further and in Article 40-c explicitly prohibited Muslim men from marrying non-Muslim women - in contradiction to Syafici fiqh. ${ }^{30}$ The reason was of pragmatic nature: the offspring of couples with a non-Muslim mother tended to adopt the mother's rather than the father's religion, and thereby contributed to the growth of non-Muslim religions in Indonesia.

Since there is no limit or penalty on individual religious conversion in Indonesia, hindrances against inter-religious marriage are usually overcome by one partner converting, at least for the letter of the law, to the partner's religion. Once partners have declared their shared religion, it is a relatively simple matter to determine whether the marriage will be certified in an Islamic or a civil court. In contrast to India, courts are little concerned with establishing proof of the litigant's religious identity. In fact, as O'Shaughnessy demonstrates through her analysis of six inter-religious marriage and divorce cases from 1987 to 2003, courts have almost completely refrained from dealing with questions of religious identity. ${ }^{31}$ Instead, the courts took litigants' declared identity at face value and did not seek to determine the authenticity of the declared religious identity. Indonesian justices were in fact quite careful not to transgress the MORA's jurisdiction by openly discussing questions of ethnic, religious identity or inter-group relations which were strictly prohibited under the New Order. ${ }^{32}$ In contrast to India, the national culture that the post-independent governments in Indonesia promoted were not unmistakably identified with one particular religion or ethnicity. While minorities in India increasingly interpreted the state's promotion of "Indianness" as a euphemism for promoting Hindu as a dominant culture, the national ethos of pancasila is not understood as a covert way for promoting Muslim-majority culture. If anything, Islamic intellectuals in the history of post-independence Indonesia saw tensions between 'Islamic ways of life' and pancasila. The fact that pancasila cannot be closely identified with any of the major religions of Indonesia is, for the purposes of nation-building, a covert blessing as it precluded the association of Indonesianness with one particular culture or religion.

30. See A.I. Mawardi, Socio-Political Background of the Enactment of Kompilasi Hukum Islam Di Indonesia, p. 61. In all Sunni schools of law, it is permitted for a Muslim man to marry a non-Muslim wife, but not the other way around. The classical sources legitimated this view with reference to women's rights. Outside Islam, a woman would likely be treated worse. Noting that children tend to follow the religious practices of their mother, with the KHI the $20^{\text {th }}$ century Indonesian state has turned Sunni fiqh around, as it tended to result in increased conversion away from Islam.

31. See K. O'Shaughnessy, Gender, State andSsocial Power in Ccontemporary Indonesia: Divorce and Marriage Law, pp. $170-177$.

32. See R.S. Kipp, Dissociated Identities: Ethnicity, Religion, and Class in an Indonesian Society, University of Michigan Press, Ann Arbor, 1993, p. 110. 


\section{The unsecular politics of democracy}

The post-1998 period has seen an important development in the realm of religion and law. As part of the democratization process, the country started in 2001 to significantly decentralize governmental functions down to the units of the districts, called 'regencies' (of which today more than 500 exist, in 33 provinces). Development and public expenditure came under purview of the sub-provincial regions of Indonesia rather than the center or the provinces. Until 2009, in more than 10\% of the country's districts, regulations were passed that signaled an Islamizing agenda (Parsons and Mietzner 2009). ${ }^{33}$ Such regulations cluster around South Sulawesi, West Java and West Sumatra and range from banning alcohol, to enforcing dress codes and curfew laws (for women who shall not walk outside without a male guardian after sundown), to compelling couples to recite the Qur'an at their wedding. ${ }^{34}$ For instance, a 2009 regulation in Tasikmalaya (West Java) specified that all Muslims must fight against corruption, fornication, prostitution, gambling, and consuming alcohol. It also pronounced as illegal: abortion, using pornography, charging interest, "practicing traditional healing if it leads people towards polytheism (syirik)", or spreading heterodox sects. ${ }^{35}$ Officials (men and women) were ordered to wear Islamic dress on Fridays, and schools were told to ensure that all pupils could recite the Qur'an. In yet other regions, the so-called sharia-based laws have had a decisively local flavor. In Bulukumba in South Sulawasi, public signs are now issued in Arabic script, arguably to play up regional specificity as an act of defiance against the culturally homogenizing policies of Jakarta. Some of these bylaws clearly violate the rights granted in the constitution, such as religious freedom (Art. 29), the equality of all recognized religions, and the equality of men and women. Despite the fact that many such regulations appear incongruent with the constitution, they are still on the books, as review mechanisms are not yet properly institutionalized or overburdened, and the Supreme Court, the final court of appeal in these matters, not sufficiently committed to deal with such regulations.

33. See N. Parsons - M. Mietzner, "Sharia By Laws in Indonesia: A Legal and Political Analysis", in The Australian Journal of Asian Law, 11, 2009, pp. 190-217.

34. On bylaws that target women, see for instance, the Rule No. 14 of 2002 issued by the Province Aceh on the Banning of Khalwat (Dating); Regional Regulation No. 15 on The Banning of Prostitution and Socially Undesirable Deeds issued by the District of Bandar Lampung; Regulation No. 3 of 2002 on Prohibition of Prostitution and Amoral Deeds enacted by the District of Lahat; Regulation No. 12 of 2003 on the Prevention of Immoral Act, put into effect by the District of Mataram; and Regulation No. 39 of 1999 on the Banning of Places Offering Commercial Sex, promulgated by the District of Kupang. Siti Musdah Mulia, Islam dan Inspirasi Kesetaran Gender, pp. 243-246.

35. Surat Ederan Bupati Cianjur No 451/2717/ASSDA.1. 
One may, as John Bowen does, ${ }^{36}$ see the sharica-based laws as new signs of provincial or regional distinctiveness and authenticity. In his account, demands for sharic $a$ are deeply situated in the history of the fight for independence against the Dutch, ensuing struggles for autonomy against Jakarta, and debates about the relative role of religion in the country's law and politics. In the post-1998 era of reform and decentralization, shar$i^{c} a$ signifies the resurgence of local capacities to define and exploit ideas of authenticity, autonomy and morality, ideas which have strong political, cultural, and often religious dimensions. Whether Bowen is right in seeing the bylaws as part of a larger process of redefining and re-legitimizing the country's institutions, or whether one should, as many observers do, consider the religious bylaws as a sign of Indonesia captured by a nation-wide religious frenzy in the aftermath of democratization and the deregulation of religion, surely democratization has changed conditions of belief. There is yet no debate, and indeed very little awareness of, the violence done unto all religions, Islam included, in the 1950-1970s due to the provisions of the MORA. There is also still very little questioning whether tying citizenship to religion is compatible with democracy and in particular with the freedom of religion guaranteed in the constitution.

\section{Conclusions}

Through bureaucratization, religion in post-independence Indonesia was not only made "manageable" but also put into the service of government policy. Alternative sources of meaning and beliefs were subjugated; those belief systems not recognized were effectively suppressed (e.g. Kejawen, Judaism, Shiism) and alternative sources of meaning within recognized religions undermined and marginalized. The type of functional conflicts regarding the relation of religious truth to other sources of truth that Gorski charts following Luhmann were made impossible through state policy that withdrew the availability of a non-religious identity. The state bureaucracy was also involved in ascertaining and defining religion, notably in requiring of Hinduism and Buddhism to fulfill certain criteria of monotheism. The state thereby became a party in the conflicts within religious communities that Gorski outlines. It did so in all four dimensions (segmentary, center/periphery, stratificatory, functional conflicts). Religious practices were redefined and "purified", creeds "rationalized" and standardized by the state, of-

36. See J. Bowen, Can Islam Be French? Pluralism and Pragmatism in a Secularist State. Princeton University Press., Princeton (N.J.), 2010. 
ten to make them "modernist", "rationalist", "humanist" and "tolerant." Agamasasi was particularly aimed to fight against communism, "to extirpate indigenous religions that do not easily support development, to meld and smooth over differences among Indonesian religions, to neutralize any influence that religious sects have to take issue with national platforms [and] to support the dissociation of religious and ethnic identities." 37

It was instrumental to reduce ethno-religious heterogeneity and promote a singular monotheistic image of religion.

Secularity III (exclusive humanism, the possibility of non-religion) in post-independence Indonesia has been subordinated to national culture, a national ethos that celebrates managed diversity. Indeed, the strong urge to nationalize is prevalent beyond the politics of managing diversity - one may also look at the attempts of the KHI to nationalize Islamic law, to mold it into an Indonesian brand sensitive of local cultural sentiments, something specifically Indonesian and thus separate from Arab or South Asian Islamic legal traditions. God is not one choice among several, Indonesian citizens only have the choice between different paths towards God. Secularity II in the sense of a diminution of religious beliefs and practices is discouraged by the state, and state policies since 1945 have actively promoted religion and religiosity, within state-sanctioned perimeters. Yet, secularity I has been a building block of the Indonesian state since 1945 and represents an overall societal consensus. The Indonesian state, both under authoritarian and democratic governments, has actively cultivated a social imaginary where one does not live in an "immanent frame", in "cosmic, social and moral orders which can be fully explained on their own terms", but instead a national frame that is expression of and works towards (1) the belief in God, (2) a just and civilized humanity, (3) national unity, (4) democracy guided by the inner wisdom of unanimity arising out of deliberations among representatives, and (5) social justice (the five pancasila principles).

Throughout the downfall of the New Order regime and transition to democracy, the pancasila- and agamasasi-based nation-building project has been, to a great extent, successful at projecting a unified national identity and creating and preserving relatively peaceful interfaith relations. Even the spirals of anti-Chinese and later Christian-Muslim violence that flared up during the Indonesian transition to democracy in 1998 - but died down again since 2002 - have not been able to undermine the overall belief that Indonesia is a multi-religious and multi-cultural society that lives of its diversity. In the post-1998 rounds of constitutional reform, those voices advocating a re-communal-

37. L.V. Aragon, Fields of the Lord: Animism, Christian Minorities, and State Development in Indonesia, p. 312. See also A. Schrauwers, Colonial "Reformation" in the Highlands of Central Sulawesi, Indonesia (1892-1995), p. 92. 
ization of the legal system remained in the minority and the pancasila character of the national constitution was eventually retained and affirmed. As Azra (2008) notes "by and large, religious diversity and peaceful coexistence among the followers of different religions in Indonesia remain intact and prospects for religious pluralism... are quite bright." 38

Taylor suggests that rather than applying a strict separationist definition of secularism, contemporary secular regimes should be thought of as such if they attempt to maximize three goods: equality (between religions, as well as between religion and non-religion), liberty (of religious belief and practice, as well as of the choice not to believe), and fraternity (inclusion of all voices in "the ongoing process of determining what the society is about (its political identity)".39 Taylor's approach aims to refute that secularism can be thought of in terms of timeless principles à la Rawls; instead, he suggests secularism must be recognized as requiring ongoing renegotiation in society. His notion of secularism is therefore not one of strict separation of religion and state, but one that balances between the three goals and in that remains responsive to changing needs of society. Indonesia's post-independence religion-state relations can be viewed in light of Taylor's three goals. Until the country's democratization in 1998, the goals of hearing all voices (fraternity) and ensuring free choice (liberty) were largely made subservient to the goal of equality (treating all recognized religions as largely equal). Fraternity was violated when the MORA imposed a monotheistic notion of religion on poly- and non-theistic faiths, and thereby promoted internal elite-driven reforms of Hinduism and Buddhism that fulfilled bureaucratic requirements. The principle of liberty was violated when MORA made state recognition of religion (agama) a requirement for citizenship, thereby de facto banning the profession of alternative faiths, including Judaism, Shi'i Islam, heterodox Sunni variants of Islam, and other local faith systems. The lacking freedom not to profess a religion (negative freedom of religion), as well as the continuing requirement for recognized religions to abide by state-sanctioned definitions are hard, if not impossible, to reconcile with the post-1998 promises of democracy. In the medium-term, constitutional jurisprudence will need to address these deficits.

Yet for Taylor, fraternity also implies maintaining "relations of harmony and comity between the supporters of different religions and Weltanschauungen." ${ }^{40}$ The policy of re-

\footnotetext{
38. A. Azra, "Religious Pluralism in Indonesia", in A. Azra, W. Hudson (eds.), Islam Beyond Conflict: Indonesian Islam and Western Political Theory, Ashgate, Aldershot-Burlington (VT), 2008, p. 119.

39. C. Taylor, Why We need a Radical Redefinition of Secularism, in E. Mendieta, J. Vanantwerpen (eds.), The Power of Religion in the Public Sphere, Columbia University Press, New York Chichester, 2011, p. 35. 40. Ibid.
} 
quiring religious identification for citizenship in Indonesia, as well as the pancasila ideology that seeks to accommodate all religions equally can be viewed as being aimed at precisely this end: maintaining relations of harmony and comity between the supporters of different religions. These relations in turn are deemed essential for inter-faith peace and appreciation for the difference of the other ("unity in diversity"). Even though the violations emerging from this policy are unambiguously evident, the Indonesian case points to the age-old trade-off between liberty and fraternity. The German constitutional theorist Ernst-Wolfgang Böckenförde formulated a version of this trade-off when he wrote in the late 1960s,

the liberal, secularized state is nourished by presuppositions that it cannot itself sustain. On the one hand, it can only survive as a liberal state if the liberty it allows its citizens regulates itself from within on the basis of the moral substance of the individual and the homogeneity of society. On the other hand, it cannot attempt to guarantee those inner regulatory forces by its own efforts - that is to say, with the instruments of legal coercion and authoritative command - without abandoning the very liberalness on which it is founded. ${ }^{41}$

The "Böckenförde dilemma", as it has become known since, points to the pre-political bases of the state. Democracies require certain degrees of cohesion and solidarity within society without which the democratic process will soon be undermined. Yet, because of their liberal commitments, democracies cannot, unlike authoritarian states, impose homogeneity and cohesion from above. Indonesia's democratization process, begun in 1998, has so far survived because these pre-political bases (a shared identity among Indonesians, a moral substance of Indonesianness) had been created in the course of the independence struggle and the subsequent regimes under Sukarno and Suharto. As much as they violated the rights of individuals and communities, pancasila and the policies of MORA undoubtedly contributed to the peaceful coexistence among followers of different religions that made the democratization process possible.

Yet, with the rounds of constitutional revisions (1999-2002) which transformed the Indonesian constitution into a liberal document able to provide the basis for a fully functioning democracy, the Indonesian state has committed itself to parting with its historical policy of creating that "moral substance" and "homogeneity" from above.

41. E.W. Böckenförde, “The Rise of the State as a Process of Secularisation”, in E.W. Böckenförde, State, Society and Liberty. Studies in Political Theory and Constitutional Law, Berg, New York-Oxford, 1991, p. 45. 
Democratization, has, as it were, turned the tables. It is now for civil society to fulfill that function and work towards nourishing the pre-political bases of the state that bind communities together. Given the historical record, religion will be a poor resource in this endeavor. 